\title{
Malaria in infants aged less than six months - is it an area of unmet medical need?
}

\author{
Umberto D'Alessandro ${ }^{1,2^{*}}$, David Ubben ${ }^{3}$, Kamal Hamed ${ }^{4}$, Serign Jawo Ceesay ${ }^{1}$, Joseph Okebe ${ }^{1}$, Makie Taal', \\ Eugene Kaman Lama ${ }^{6}$, Moussa Keita ${ }^{6}$, Lamine Koivogui ${ }^{6}$, Alain Nahum ${ }^{7}$, Kalifa Bojang ${ }^{1}$, Aja Adam Jagne Sonko ${ }^{5}$, \\ Honorat Francis Lalya ${ }^{8}$ and Bernard Brabin ${ }^{9}$
}

\begin{abstract}
Despite the protection provided by several factors, including maternal antibodies, the burden of malaria in young infants may be higher than previously thought. Infants with congenital or neonatal malaria may have a different clinical presentation than older children, and diagnosis may be confused with other neonatal diseases due to an overlap of clinical manifestations. In addition, there is little information on the use of artemisinin-based combination therapy in young infants. There is the need for a more accurate estimate of the parasite prevalence and the incidence of clinical malaria in infants under 6 months old, as well as a better characterization of risk factors, pharmacokinetic profiles, safety and efficacy of currently available anti-malarial treatments, in order to develop evidence-based treatment guidelines for this population.
\end{abstract}

Keywords: Malaria, Neonate, Congenital, Prevalence, Parasitaemia, Artemisinin-based combination therapy

\section{Background}

Although the burden of Plasmodium falciparum malaria in children aged under five years is well documented [1], there is limited and contradictory information about the impact of the disease in infants under six months of age. Early studies concluded that malaria was uncommon in young infants and that clinical disease was of little importance [2-4], despite several early reports of a uniform rise in parasite prevalence during the first few months of life [5]. Young infants with malaria may have different clinical manifestations [6,7] and lower parasite densities [5] than older children. Nevertheless, even low-density infections $(1-500$ parasites $/ \mu \mathrm{L})$ in infants can result in anaemia if left untreated [8], and may rapidly progress to become life-threatening [9].

Neonatal malaria is considered a rare occurrence due to the protective effect of maternal immunity after birth. Maternal immunoglobulin G (IgG) antibodies are acquired by the fetus via the placenta in utero [10], although there is only limited evidence suggesting a protective role of these passively acquired antibodies against

\footnotetext{
* Correspondence: udalessandro@mrc.gm

${ }^{1}$ Medical Research Council Unit, PO Box 273, Banjul, The Gambia

Institute of Tropical Medicine, Nationalestraat 155, 2000, Antwerp, Belgium Full list of author information is available at the end of the article
}

malaria parasites [11]. IgG levels are thought to decrease variably during the first year of life [12]. Neonates may also be protected through factors that inhibit parasite growth, such as lactoferrin (which binds iron) and secretory IgA, found in breast milk and in maternal and infant sera [13]. Parasite replication depends on the metabolic substrate para-aminobenzoic acid (pABA), which is present only in low levels in breast milk [10]. Haemoglobin $\mathrm{F}(\mathrm{HbF})$, present in high concentrations at birth [10], can inhibit parasite development [14] and can protect the infant in the first few months of life. The parasite antigen $P$. falciparum erythrocyte membrane protein-1 (PfEMP-1) mediates cytoadherence of infected red blood cells to the endothelial cells lining the blood vessels. $\mathrm{HbF}$ and maternal IgG act cooperatively to impair the cytoadherence of parasitized erythrocytes in the first few months of life by altering PfEMP-1 display on HbF RBCs, and by binding PfEMP-1 and preventing sequestration of parasitized RBCs, respectively [15]. $\mathrm{HbF}$ levels decline after a peak at 6 weeks of age [10], and as both $\mathrm{HbF}$ and IgG disappear from circulation, infant susceptibility to P. falciparum malaria increases [15].

Iron-deficiency anaemia is common in sub-Saharan Africa and can cause impaired cognitive and motor development, growth impairment and anorexia. Consequently, 
in many areas, iron supplementation is recommended in children below two years of age. However, iron status has been shown to have an effect on the risk of malaria in young infants, with iron deficiency potentially causing a decrease in malaria morbidity and mortality [16].

In Mozambique and Benin, placental malaria has been associated with shorter time to first episode of infant malaria $[17,18]$. The mechanisms underlying this association are unclear but may relate to prenatal foetal priming [19]. Therefore, some reduction of malaria risk in infants can probably be achieved by improving malaria control in late pregnancy.

\section{Burden of malaria in infants aged less than six months}

Malaria in infants is classified according to the time of infection. Congenital malaria, defined as asexual parasites detected in the cord blood or in the peripheral blood during the first week of life [20], is due to transmission from the mother through the placenta just before or during delivery [21], while neonatal malaria, which can occur within the first 28 days of life, is due to an infective mosquito bite after birth [21]. Differentiating between congenital and acquired neonatal malaria can be difficult, especially in areas of intense malaria transmission [22]. Various studies across Africa have demonstrated that $7-10 \%$ of newborns may have malaria parasites in their cord blood [8], in some cases either without evidence of an active maternal infection or with parasite genotypes different to those found in the mother. This suggests transplacental passage of parasites followed by clearance from maternal and placental blood, with persistence in the foetus [8,23,24].

Recent reports suggest that malaria in infants under six months of age may not be uncommon, although data on prevalence and outcome are still contradictory [25]. Prevalence of infection can vary between $0 \%$ and $27 \%$ [9,25-33], while the percentage of deaths attributed to malaria (as determined by verbal autopsy) may be between $20.1 \%$ and $46.2 \%$ [34]. The occurrence of infection in utero is also reflected by the prevalence of splenomegaly at one month of age, which can be as high as $80 \%$, indicating an early development of a splenic response to the infection $[5,35]$.

In Mozambique, clinical malaria incidence in infants aged $1-<6$ months was substantial $(320 / 1,000$ childyears at risk in 2003-2004 and 146/1,000 child-years at risk in 2004-2005) [36]. Reports of congenital malaria have predominantly come from Nigeria; the prevalence of parasitaemia in infants in these studies as well as in those from other malaria-endemic regions varied widely between $0.7 \%$ and $46.7 \%$ [20,33,37-51]. Parasite densities in neonatal blood were also varied, although most infections were of low density [20,40,42,48-50,52,53].
However, differences in transmission dynamics, small sample sizes and lack of details on quality control and sample selection procedures make the interpretation of these findings difficult $[20,25]$.

Malaria infections (mean geometric parasite density = 533 parasites/ $\mu$ l of blood, as detected by PCR) were common in Ghanaian infants less than 6 months of age (13.6\% in newborns; $1.5-9.7 \%$ in those aged from 226 weeks), although clinical malaria symptoms were rare or uncommon (fever, vomiting, diarrhoea and coughing occurred in $1.8 \%, 1.8 \%, 3.0 \%$ and $4.8 \%$ of infants aged $0-$ 3 months, respectively, and in $4.5 \%, 3.0 \%, 8.0 \%$ and $10.6 \%$ of infants aged 3-6 months) [54]. In Mozambique, although malaria in infants aged under six months represented less than $20 \%$ of the total outpatient visits, infants with malaria were admitted in a significantly higher proportion than children aged 1-4 years [36]. The impact of malaria in this age group is also illustrated by a greater difference in mean haematocrit between malaria and non-malaria cases in infants aged from 2-12 months (4.9\%) than in children aged 5 years or above (1.8\%). Among infants aged under six months attending an urban hospital in Nigeria, $27.1 \%$ had a positive blood slide and a significantly lower haematocrit (33.0\%) compared with those who were uninfected $(35.1 \%)(\mathrm{p}=0.003)$. Indeed, a haematocrit of less than $33 \%$ was the most common clinical finding among infected infants, while the occurrence of fever was $4 \%$ [9].

A systematic review of age-patterns of malaria revealed that as transmission increased, there was a shift of clinical malaria towards younger age groups, regardless of seasonality [55]. As transmission intensity increased and seasonality decreased, severe cases became more frequent in the younger ages. Nevertheless, wherever a comparison between age groups was possible, malaria mortality was higher in younger children, with the peak age shifting towards infants as transmission became more intense [55].

\section{Clinical signs and symptoms and malaria diagnosis in infants aged under six months}

Signs and symptoms of congenital malaria include fever, anaemia, splenomegaly, hepatomegaly, jaundice, vomiting, diarrhoea, poor feeding, restlessness, drowsiness, pallor, respiratory distress, cyanosis, and possibly convulsions $[39,56]$.

Malaria in young infants may be asymptomatic [6,7], or it may be difficult to diagnose because the clinical presentation may mimic other diseases, such as sepsis [33]. Indeed, congenital malaria may be more common in newborns with suspected or confirmed sepsis (28.6\%) $[38,47]$. It is unclear what influence infant HIV infection has on these risks. 
In areas with limited resources, the capacity to diagnose malaria in young infants may be limited $[57,58]$, and any issues with quality or accuracy of the diagnostic technique may result in the diagnosis of malaria being missed [59]. In many malaria-endemic countries, infants and children frequently die at home [60] and the cause of death remains undetermined and unrecorded $[17,34,61]$. Therefore, the overall malaria mortality in infants aged under six months is highly uncertain. As approximately $40 \%$ of all child deaths occur in the neonatal period, and many deliveries occur outside health facilities, the proportion of these deaths that is malariarelated is unclear [60].

\section{Pharmacokinetics of anti-malarials in young infants}

Due to the dynamic developmental changes experienced by infants aged under 6 months, the pharmacokinetic profiles of anti-malarials may be different than in older children, and age-dependent dose adjustments may be necessary [62]. For example, gastric emptying is slower in neonates and young infants, and is only comparable with adults after six months of age. Absorption of drugs is also affected by intestinal motor activity and villous formation, both of which mature by week 20 [62]. Drug metabolism may be altered as enzyme systems, such as the hepatic enzymes, are immature (anti-malarials are typically metabolized in the liver) [63], possibly resulting in an enhancement of bioavailability [62]. Activity of such metabolizing enzymes is typically low at birth and rapidly develops over the first 1-2 years of life [64].

\section{Current national recommendations for treating infants aged under 6 months}

As the burden of disease in infants under 6 months of age is not well defined, this age group has been excluded from previous clinical trials and national treatment guidelines on uncomplicated $P$. falciparum malaria. Thus, oral anti-malarials recommended as first- and second-line therapies are frequently used off-label, based on the recommended $\mathrm{mg} / \mathrm{kg}$ dosing schedule for older children [28].

\section{Issues with currently available anti-malarials}

There is little information on the use of artemisininbased combination therapy (ACT) in young infants, to the extent that many of them carry label restrictions for this age group [63]. Accurate dosing is particularly important, but this is difficult when paediatric formulations are unavailable. Nevertheless, young infants with malaria should receive appropriate treatment. Among the recommended ACT, excluding the combination containing sulphadoxine-pyrimethamine that is not recommended during the first 6 weeks of life [65], there is no evidence of specific serious toxicity [63]. However, additional efforts should be made to establish their safety profile, the correct dosage and formulation, so that young infants with malaria can be managed adequately.

With these issues in mind, it must be considered how ACT could be used to treat malaria in infants aged under six months. There are no official data on how to use ACT in this age group, despite the fact that malaria can occur at a very young age and that ACT offers greater efficacy and tolerability compared with quinine, which is often used in infants with clinical malaria. Furthermore, the use of a unified first-line therapy could offer benefits for healthcare providers with similar antimalarial use for the whole population, as well as logistical benefits in terms of procurement and distribution. The safety profile of these combination therapies in young infants should be established.

\section{Preventive treatment}

Previous studies have shown that chemoprophylaxis in infants has the potential to reduce malaria-related morbidity and mortality [66]. In The Gambia, infants receiving weekly chloroquine from birth until the age of two years had fewer episodes of malaria, grew better, and had higher haemoglobin levels than the control group [67].

Some studies of intermittent preventive treatment (IPT) in infants (IPTi) have timed the doses of antimalarial to coincide with routine vaccinations delivered by WHO's Expanded Programme on Immunization (EPI) at 2, 3 and 9 months. In a pooled analysis of six randomized, placebo-controlled trials of IPTi using sulphadoxine-pyrimethamine delivered at the same time as EPI immunizations, a protective efficacy against clinical malaria of $30.3 \%$ was reported [68].

Seasonal malaria chemoprevention (SMC), previously referred to as IPT in children (IPTc), involves the administration of full anti-malarial treatment courses during the malaria season to children aged 3-59 months [69]. The WHO recommends that SMC be used in areas of high seasonal malaria transmission across sub-Saharan Africa, and that treatment with amodiaquine plus sulphadoxine-pyrimethamine should be given at monthly intervals from the start of the transmission season, up to a maximum of four doses [69]. The main potential risks associated with SMC are safety and drug resistance [70]. However, SMC may provide a substantial protective effect against malaria [70], and is a potentially valuable tool that could contribute to reducing the malaria burden in infants aged over three months in areas with seasonal transmission.

The candidate malaria vaccine RTS,S/AS01 administered to infants aged 6-12 weeks at the time of the first vaccination provided modest protection against both 
uncomplicated and severe malaria [71], casting doubts on whether this vaccine could be included in the routine panel of infants' immunization [72]. However, additional analyses are needed to understand the reasons of the observed lower efficacy in young infants as compared with older infants and children (aged 5-17 months) [73].

\section{Future clinical studies}

There are several ongoing or planned clinical studies aiming to obtain more accurate estimates of the malaria burden and parasite prevalence in infants aged less than 6 months living under different endemic conditions, as well as the safety and efficacy of currently available ACT in this population. Future longitudinal studies should also characterize infant iron status in relation to subsequent malaria risk, and relate findings to the occurrence of placental malaria.

A multicentre descriptive study is underway, aiming to assess malaria morbidity (prevalence and incidence) and corresponding risk factors in young infants, compared with their siblings, in areas of seasonal low (The Gambia) and high (Guinea) malaria transmission, and in an area with intense, perennial transmission (Benin).

A multicentre trial will evaluate the safety, pharmacokinetics and efficacy of dispersible artemetherlumefantrine tablets in infants weighing under $5 \mathrm{~kg}$ with uncomplicated P. falciparum malaria. This trial, sponsored by Novartis and in association with MMV, commenced in 2012 and involves sites in Benin, Burkina Faso, the Democratic Republic of the Congo, Nigeria and Togo.

Another study planned at the College of Medicine at the University of Malawi will assess the population pharmacokinetics and the safety and efficacy of ACT in infants weighing under $5 \mathrm{~kg}$ or aged less than 6 months.

Knowledge gained from such studies will assist in guiding the development of evidence-based treatment guidelines for this population.

\section{Conclusions}

The perception that malaria is uncommon in young infants has resulted in the paucity of information currently available and the lack of evidence-based treatment guidelines in this population. Many children are dying before malaria is diagnosed. In resource-constrained settings, diagnostic techniques may not be available, or malaria may not be recognized due to overlapping symptoms with other neonatal illnesses such as sepsis [33]. Malaria in infants aged under six months is not a rare occurrence in endemic areas and its burden may be underestimated. Therefore, it is necessary to collect reliable data on the malaria burden in this population. Awareness by health professionals should increase so that any infant aged under 6 months brought to a health facility in a malaria-endemic area with unexplained fever or suspected sepsis should be systematically screened for malaria. Current policy for malaria diagnosis dictates that all fevers in all age groups and settings should be tested for malaria before treatment is initiated.

ACT is being used off-label in this vulnerable patient group, with physicians using a pragmatic approach to guide dosing. At this time, a clear recommendation on the use of ACT could be difficult, due to a lack of data in infants with a body weight of less than $5 \mathrm{~kg}$ (less than $4.5 \mathrm{~kg}$ for artesunate plus amodiaquine). A more accurate estimate of the disease burden and parasite prevalence, risk factors for infection including iron status, as well as the pharmacokinetic profiles, safety and efficacy of currently available ACT in early infancy from data provided by clinical trials that are planned or underway will contribute to the development of evidence-based treatment guidelines for this population, as well as aid the research and development of new drugs. It is definitely worth providing malaria control strategies that are aimed directly at this vulnerable age group, in a bid to reduce infant mortality.

\section{Abbreviations}

ACT: Artemisinin-based combination therapy; EPI: Expanded Programme on Immunization; HbF: Haemoglobin F; HIV: Human Immunodeficiency Virus; IgA: Immunoglobulin A; IgG: Immunoglobulin G; IPT: Intermittent preventive treatment; IPTc: Intermittent preventive treatment in children;

IPTi: Intermittent preventive treatment in infants; MMV: Medicines for Malaria Venture; PABA: Para-aminobenzoic acid; PCR: Polymerase Chain Reaction; PfEMP-1: Plasmodium falciparum erythrocyte membrane protein-1;

SMC: Seasonal malaria chemoprevention; WHO: World Health Organization.

\section{Competing interests}

UD has been invited as speaker at symposia organized by Sigma Tau and Novartis Pharma, and has received a research grant from Sigma Tau. KH is an employee of Novartis Pharmaceuticals Corporation, East Hanover, NJ, USA. This declaration is made in the interest of full disclosure and not because the author considers this to be a competing interest. The other authors have no competing interest to declare.

\section{Authors' contributions}

All authors met International Committee of Medical Journal Editors criteria for authorship. All authors contributed to the development of the outline, revised the manuscript critically, and read and approved the final manuscript.

\section{Acknowledgements}

Editorial assistance was provided by Caroline Sharp (PreScript Communications), with funding from MMV.

\section{Author details}

${ }^{1}$ Medical Research Council Unit, PO Box 273, Banjul, The Gambia. ${ }^{2}$ Institute of Tropical Medicine, Nationalestraat 155, 2000, Antwerp, Belgium. ${ }^{3}$ Medicines for Malaria Venture (MMV), PO Box 182620 rte de Pré-Bois, 1215, Geneva 15, Switzerland. ${ }^{4}$ Novartis Pharmaceuticals Corporation, One Health Plaza, East Hanover, NJ 07936-01080, USA. ${ }^{5}$ Ministry of Health and Social Welfare, The Quadrangle, Banjul, The Gambia. ${ }^{6}$ Ministry of Health, BP 6623, Conakry, Guinea. ${ }^{7}$ Centre de Recherches Entomologiques de Cotonou, Cotonou, Benin. ${ }^{8}$ Centre National Hospitalier Universitaire Hubert K. Maga, Cotonou, Benin. ${ }^{9}$ Child and Reproductive Health Group, Liverpool School of Tropical Medicine, Pembroke Place, Liverpool L35QA, UK. 
Received: 11 October 2012 Accepted: 28 November 2012

Published: 2 December 2012

\section{References}

1. WHO: World malaria report. Geneva: World Health Organization; 2011.

2. Macdonald G: The analysis of malaria parasite rates in infants. Trop Dis Bull 1950, 47:915-938.

3. Foll CV: Application of malariometric data obtained from longitudinal studies on infants in northern Nigeria. Bull World Health Organ 1968, 38:255-265

4. Thomson JG: Malaria in nyasaland: (section of tropical diseases and parasitology). Proc R Soc Med 1935, 28:391-404.

5. Brabin B: An analysis of malaria parasite rates in infants: 40 years after Macdonald. Trop Dis Bull 1990, 87:1-21.

6. Biggar RJ, Collins WE, Campbell CC: The serological response to primary malaria infection in urban Ghanaian infants. AmJTrop Med Hyg 1980, 29:720-724.

7. Sehgal VM, Siddjiqui WA, Alpers MP: A seroepidemiological study to evaluate the role of passive maternal immunity to malaria in infants. Trans R Soc Trop Med Hyg 1989, 83(Suppl):105-106.

8. Fischer PR: Malaria and newborns. J Trop Pediatr 2003, 49:132-134.

9. Afolabi BM, Salako LA, Mafe AG, Ovwigho UB, Rabiu KA, Sanyaolu NO, Ibrahim MM: Malaria in the first 6 months of life in urban African infants with anemia. AmJTrop Med Hyg 2001, 65:822-827.

10. Riley EM, Wagner GE, Akanmori BD, Koram KA: Do maternally acquired antibodies protect infants from malaria infection? Parasite Immunol 2001, 23:51-59.

11. Riley EM, Wagner GE, Ofori MF, Wheeler JG, Akanmori BD, Tetteh $\mathrm{K}$, McGuinness D, Bennett S, Nkrumah FK, Anders RF, Koram KA: Lack of association between maternal antibody and protection of African infants from malaria infection. Infect Immun 2000, 68:5856-5863.

12. Doolan DL, Dobano C, Baird JK: Acquired immunity to malaria. Clin Microbiol Rev 2009, 22:13-36. Table.

13. Kassim OO, Ako-Anai KA, Torimiro SE, Hollowell GP, Okoye VC, Martin SK: Inhibitory factors in breastmilk, maternal and infant sera against in vitro growth of Plasmodium falciparum malaria parasite. J Trop Pediatr 2000, 46:92-96.

14. Gitau GM, Eldred JM: Malaria in pregnancy: clinical, therapeutic and prophylactic considerations. Obstet Gynaecol 2005, 7:5-11.

15. Amaratunga C, Lopera-Mesa TM, Brittain NJ, Cholera R, Arie T, Fujioka H, Keefer JR, Fairhurst RM: A role for fetal hemoglobin and maternal immune lgG in infant resistance to Plasmodium falciparum malaria. PLoS One 2011, 6:e14798.

16. Gwamaka M, Kurtis JD, Sorensen BE, Holte S, Morrison R, Mutabingwa TK, Fried M, Duffy PE: Iron deficiency protects against severe Plasmodium falciparum malaria and death in young children. Clin Infect Dis 2012, 54:1137-1144

17. Bardaji A, Sigauque B, Sanz S, Maixenchs M, Ordi J, Aponte JJ, Mabunda S, Alonso PL, Menéndez C: Impact of malaria at the end of pregnancy on infant mortality and morbidity. J Infect Dis 2011, 203:691-699.

18. Schwarz NG, Adegnika AA, Breitling LP, Gabor J, Agnandji ST, Newman RD, Lell B, Issifou S, Yazdanbakhsh M, Luty AJ, Kremsner PG, Grobusch MP. Placental malaria increases malaria risk in the first 30 months of life. Clin Infect Dis 2008, 47:1017-1025.

19. Malhotra I, Dent A, Mungai P, Wamachi A, Ouma JH, Narum DL, Muchiri E, Tisch DJ, King CL: Can prenatal malaria exposure produce an immune tolerant phenotype? A prospective birth cohort study in Kenya. PLoS Med 2009, 6:e1000116.

20. Falade C, Mokuolu O, Okafor H, Orogade A, Falade A, Adedoyin O, Oguonu T, Aisha M, Hamer DH, Callahan MV: Epidemiology of congenital malaria in Nigeria: a multi-centre study. Trop Med Int Health 2007, 12:1279-1287.

21. Mukhtar M: The growing incidence of neonatal malaria-a situational review in developing countries. Niger J Med 2007, 16:25-30.

22. Fischer PR, Nyirjesy P, Toko RM: Congenital malaria in twins. West J Med 1995, 163:395-396.

23. Fischer PR: Congenital malaria: an African survey. Clin Pediatr (Phila) 1997, 36:411-413.

24. Kamwendo DD, Dzinjalamala FK, Snounou G, Kanjala MC, Mhango CG, Molyneux ME, Rogerson SJ: Plasmodium falciparum: PCR detection and genotyping of isolates from peripheral, placental, and cord blood of pregnant Malawian women and their infants. Trans $R$ Soc Trop Med Hyg 2002, 96:145-149.

25. Mwaniki MK, Talbert AW, Mturi FN, Berkley JA, Kager P, Marsh K, Newton CR: Congenital and neonatal malaria in a rural Kenyan district hospital: an eight-year analysis. Malar J 2010, 9:313.

26. Dicko-Traoré F, Syla M, Djimde AA, Diakité AA, Diawara M, Togo B, Togo P, Dara A, Dama S, Traoré K, Traoré S, Sissoko S, Poudiougo B, Sidibé T, Keita $\mathrm{MM}$, Doumbo O: [Congenital and neonatal malaria in sub-sahara Africa, a scarce event?]. J Pediatr Pueric 2011, 24:57-61.

27. Klein Klouwenberg PM, Oyakhirome S, Schwarz NG, Glaser B, Issifou S, Kiessling G, Klöpfer A, Kremsner PG, Längin M, Lassmann B, Necek M, Pötschke M, Ritz A, Grobusch MP: Malaria and asymptomatic parasitaemia in Gabonese infants under the age of 3 months. Acta Trop 2005, 95:81-85.

28. Larru B, Molyneux E, ter Kuile FO, Taylor T, Molyneux M, Terlouw DJ: Malaria in infants below six months of age: retrospective surveillance of hospital admission records in Blantyre. Malawi. Malar J 2009, 8:310.

29. Nankabirwa V, Tylleskar T, Nankunda J, Engebretsen IM, Sommerfelt $H$, Tumwine JK: Malaria parasitaemia among infants and its association with breastfeeding peer counselling and vitamin A supplementation: a secondary analysis of a cluster randomized trial. PLoS One 2011, 6:e21862.

30. Pedro R, Akech S, Fegan G, Maitland K: Changing trends in blood transfusion in children and neonates admitted in Kilifi District Hospital. Kenya. Malar J 2010, 9:307.

31. Runsewe-Abiodun IT, Ogunfowora OB, Fetuga BM: Neonatal malaria in Nigeria-a 2 year review. BMC Pediatr 2006, 6:19

32. van Eijk AM, Ayisi JG, ter Kuile FO, Slutsker L, Shi YP, Udhayakumar V, Otieno JA, Kager PA, Lal RB, Steketee RW, Nahlen BL: HIV, malaria, and infant anemia as risk factors for postneonatal infant mortality among HIVseropositive women in Kisumu. Kenya. J Infect Dis 2007, 196:30-37.

33. Ojukwu JU, Ezeonu CT, Ogbu CN: Severe malaria in neonates masquerading as septicaemia. Nigerian J Paediatr 2004, 31:48-55.

34. Abdullah S, Adazu K, Masanja H, Diallo D, Hodgson A, llboudo-Sanogo E, Nhacolo A, Owusu-Agyei S, Thompson R, Smith T, Binka FN: Patterns of age-specific mortality in children in endemic areas of sub-Saharan Africa. AmJTrop Med Hyg 2007, 77:99-105.

35. Corkill JA, Brabin BJ, MacGregor DF, Alpers MP, Milner RD: Newborn splenic volumes vary under different malaria endemic conditions. Arch Dis Child 1989, 64:541-545.

36. Guinovart C, Bassat Q, Sigauque B, Aide P, Sacarlal J, Nhampossa T, Bardají A, Nhacolo A, Macete E, Mandomando I, Aponte JJ, Menéndez C, Alonso PL: Malaria in rural Mozambique. Part l: children attending the outpatient clinic. Malar J 2008, 7:36.

37. Adja EA, Dick FA, N'guessan R: [Epidemiological study of the malaria at the neonatal period in the teaching hospital of Yopougon-Republic of Cote d'Ivoire] (in French). Mali Med 2009, 24:36-39.

38. Ekanem $A D$, Anah MU, Udo JJ: The prevalence of congenital malaria among neonates with suspected sepsis in Calabar. Nigeria. Trop Doct 2008, 38:73-76.

39. Ibhanesebhor SE: Clinical characteristics of neonatal malaria. J Trop Pediatr 1995, 41:330-333.

40. Lesi FE, Mukhtar MY, Iroha EU, Egri-Okwaji MT: Clinical presentation of congenital malaria at the Lagos university teaching hospital. Niger I Clin Pract 2010, 13:134-138.

41. Mosha TCE, Ntarukimana D, John M: Prevalence of congenital malaria among neonates at morogoro regional hospital, morogoro. Tanzania. Tanzania J Health Res 2010, 12:1-10.

42. Mukhtar MY, Lesi FE, Iroha EU, Egri-Okwaji MT, Mafe AG: Congenital malaria among inborn babies at a tertiary centre in Lagos. Nigeria. J Trop Pediatr 2006, 52:19-23.

43. Mwangoka GW, Kimera SI, Mboera LE: Congenital Plasmodium falciparum infection in neonates in Muheza District. Tanzania. Malar J 2008, 7:117.

44. Obiajunwa PO, Owa JA, Adeodu OO: Prevalence of congenital malaria in Ile-ife. Nigeria. J Trop Pediatr 2005, 51:219-222

45. Oduwole OA, Ejezie GC, Odey FA, Oringanje CM, Nwakanma D, Bello S, Oriero E, Okebe J, Alaribe AA, Etuk S, Meremikwu M: Congenital malaria in Calabar, Nigeria: the molecular perspective. AmJTrop Med Hyg 2011, 84:386-389.

46. Okafor UH, Oguonu T, Onah HE: Risk factors associated with congenital malaria in Enugu. South eastern Nigeria. J Obstet Gynaecol 2006, 26:612-616 
47. Okechukwu AA, Olateju EK, Olutunde EO: Congenital malaria among newborns admitted for suspected neonatal sepsis in Abuja. Nigerian $J$ Paediatr 2011, 38:82-89.

48. Omalu IC, Mgbemena C, Mgbemena A, Ayanwale V, Olayemi IK, Lateef A, Chukwuemeka VI: Prevalence of congenital malaria in Minna, north central Nigeria. J Trop Med 2012, 201 (2):274142.

49. Orogade AA, Falade CO, Okafor HU, Mokuolu OA, Mamman Al, Ogbonu TA, Ogunkunle OO, Ernest KS, Callahan MV, Hamer DH: Clinical and laboratory features of congenital malaria in Nigeria. J Pediatr Infect Dis 2008, 3:181-187.

50. Pineros-Jimenez JG, Alvarez G, Tobon A, Arboleda M, Carrero S, Blair S: Congenital malaria in Uraba. Colombia. Malar J 2011, 10:239.

51. Sule-Odu AO, Ogunledun A, Olatunji AO: Impact of asymptomatic maternal malaria parasitaemia at parturition on perinatal outcome. J Obstet Gynaecol 2002, 22:25-28.

52. Larkin GL, Thuma PE: Congenital malaria in a hyperendemic area. AmJTrop Med Hyg 1991, 45:587-592.

53. Akindele JA, Sowunmi A, Abohweyere AE: Congenital malaria in a hyperendemic area: a preliminary study. Ann Trop Paediatr 1993, 13:273-276

54. Wagner G, Koram K, McGuinness D, Bennett S, Nkrumah F, Riley E: High incidence of asymptomatic malara infections in a birth cohort of children less than one year of age in Ghana, detected by multicopy gene polymerase chain reaction. AmJTrop Med Hyg 1998, 59:115-123.

55. Carneiro I, Roca-Feltrer A, Griffin JT, Smith L, Tanner M, Schellenberg JA, Greenwood B, Schellenberg D: Age-patterns of malaria vary with severity, transmission intensity and seasonality in sub-Saharan Africa: a systematic review and pooled analysis. PLoS One 2010, 5:e8988.

56. Hashemzadeh A, Heydarian F: Congenital malaria in a neonate. Arch Iranian Med 2005, 8:226-228.

57. Hailegiorgis B, Girma S, Melaku Z, Teshi T, Demeke L, Gebresellasie S, Yadeta D, Tibesso G, Whitehurst N, Yamo E, Carter J, Reithinger R: Laboratory malaria diagnostic capacity in health facilities in five administrative zones of oromia regional state. Ethiopia. Trop Med Int Health 2010, 15:1449-1457.

58. Ishengoma DR, Derua YA, Rwegoshora RT, Tenu F, Massaga JJ, Mboera LE, Magesa SM: The performance of health laboratories and the quality of malaria diagnosis in six districts of Tanzania. Ann Trop Med Parasitol 2010, 104:123-135.

59. Uneke CJ: Congenital Plasmodium falciparum malaria in sub-Saharan Africa: a rarity or frequent occurrence? Parasitol Res 2007, 101:835-842.

60. Lawn JE, Cousens S, Zupan J: 4 million neonatal deaths: when? Where? Why? Lancet 2005, 365:891-900.

61. Sacarlal J, Nhacolo AQ, Sigauque B, Nhalungo DA, Abacassamo F, Sacoor CN, Aide P, Machevo S, Nhampossa T, Macete EV, Bassat Q, David C, Bardají A, Letang E, Saúte F, Aponte JJ, Thompson R, Alonso PL: A 10 year study of the cause of death in children under 15 years in Manhica. Mozambique. BMC Publ Health 2009, 9:67.

62. Kearns GL, Abdel-Rahman SM, Alander SW, Blowey DL, Leeder JS, Kauffman RE: Developmental pharmacology-drug disposition, action, and therapy in infants and children. N Engl J Med 2003, 349:1157-1167.

63. WHO: Guidelines for the treatment of Malaria. Secondth edition. Geneva, Switzerland: World Health Organization; 2010.

64. Milsap RL, Jusko WJ: Pharmacokinetics in the infant. Environ Health Perspect 1994, 102(Suppl 11):107-110.

65. Menendez C, Mayor A: Congenital malaria: the least known consequence of malaria in pregnancy. Semin Fetal Neonatal Med 2007, 12:207-213.

66. Geerligs PD, Brabin BJ, Eggelte TA: Analysis of the effects of malaria chemoprophylaxis in children on haematological responses, morbidity and mortality. Bull World Health Organ 2003, 81:205-216.

67. McGregor IA, Gilles HM, Walters JH, Davies AH, Pearson FA: Effects of heavy and repeated malarial infections on Gambian infants and children; effects of erythrocytic parasitization. BMJ 1956, 2:686-692

68. Aponte JJ, Schellenberg D, Egan A, Breckenridge A, Carneiro I, Critchley J, Danquah I, Dodoo A, Kobbe R, Lell B, May J, Premji Z, Sanz S, Sevene E, Soulaymani-Becheikh R, Winstanley P, Adjei S, Anemana S, Chandramohan D, Issifou S, Mockenhaupt F, Owusu-Agyei S, Greenwood B, Grobusch MP, Kremsner PG, Macete E, Mshinda H, Newman RD, Slutsker L, Tanner M, Alonso P, Menendez C: Efficacy and safety of intermittent preventive treatment with sulfadoxine-pyrimethamine for malaria in African infants: a pooled analysis of six randomised, placebo-controlled trials. Lancet 2009, 374:1533-1542.

69. WHO Global Malaria Programme: WHO Policy Recommendation: Seasonal Malaria Chemoprevention (SMC) for Plasmodium falciparum malaria control in highly seasonal transmission areas of the Sahel sub-region in Africa: ; 2012 http://www.who.int/malaria/publications/atoz/ smc_policy_recommendation_en_032012.pdf.

70. Gosling RD, Okell L, Mosha J, Chandramohan D: The role of antimalarial treatment in the elimination of malaria. Clin Microbiol Infect 2011, 17:1617-1623.

71. The RTS,S Clinical Trials Partnership: A phase 3 trial of RTS,S/AS01 malaria vaccine in African infants. N Engl J Med 2012, (). doi:10.1056/ NEJMoa1208394.

72. Daily JP: Malaria vaccine trials - beyond efficacy end points. N Engl J Med 2012, doi:10.1056/NEJMe1213392.

73. Agnandji ST, Lell B, Soulanoudjingar SS, Fernandes JF, Abossolo BP, Conzelmann C, Methogo BG, Doucka Y, Flamen A, Mordmüller B, Issifou S, Kremsner PG, Sacarlal J, Aide P, Lanaspa M, Aponte JJ, Nhamuave A, Quelhas D, Bassat Q, Mandjate S, Macete E, Alonso P, Abdulla S, Salim N, Juma O, Shomari M, Shubis K, Machera F, Hamad AS, Minja R, Mtoro A, Sykes A, Ahmed S, Urassa AM, Ali AM, Mwangoka G, Tanner M, Tinto H, D’Alessandro U, Sorgho H, Valea I, Tahita MC, Kaboré W, Ouédraogo S, Sandrine Y, Guiguemdé RT, Ouédraogo JB, Hamel MJ, Kariuki S, Odero C, Oneko M, Otieno K, Awino N, Omoto J, Williamson J, Muturi-Kioi V, Laserson KF, Slutsker L, Otieno W, Otieno L, Nekoye O, Gondi S, Otieno A, Ogutu B, Wasuna R, Owira V, Jones D, Onyango AA, Njuguna P, Chilengi R, Akoo P, Kerubo C, Gitaka J, Maingi C, Lang T, Olotu A, Tsofa B, Bejon P, Peshu N, Marsh K, Owusu-Agyei S, Asante KP, Osei-Kwakye K, Boahen O, Ayamba S, Kayan K, Owusu-Ofori R, Dosoo D, Asante I, Adjei G, Adjei G, Chandramohan D, Greenwood B, Lusingu J, Gesase S, Malabeja A, Abdul O, Kilavo H, Mahende C, Liheluka E, Lemnge M, Theander T, Drakeley C, Ansong D, Agbenyega T, Adjei S, Boateng HO, Rettig T, Bawa J, Sylverken J, Sambian D, Agyekum A, Owusu L, Martinson F, Hoffman I, Mvalo T, Kamthunzi P, Nkomo R, Msika A, Jumbe A, Chome N, Nyakuipa D, Chintedza J, Ballou WR, Bruls $M$, Cohen J, Guerra Y, Jongert E, Lapierre D, Leach A, Lievens M, OforiAnyinam O, Vekemans J, Carter T, Leboulleux D, Loucq C, Radford A, Savarese B, Schellenberg D, Sillman M, Vansadia P: RTS,S Clinical Trials Partnership: First results of phase 3 trial of RTS,S/AS01 malaria vaccine in African children. N Engl J Med 2011, 365:1863-1875.

doi:10.1186/1475-2875-11-400

Cite this article as: D'Alessandro et al.: Malaria in infants aged less than six months - is it an area of unmet medical need?. Malaria Journal 2012 11:400.

\section{Submit your next manuscript to BioMed Central and take full advantage of:}

- Convenient online submission

- Thorough peer review

- No space constraints or color figure charges

- Immediate publication on acceptance

- Inclusion in PubMed, CAS, Scopus and Google Scholar

- Research which is freely available for redistribution 